\title{
An Evaluation of the Mitigating Effects of A-Tocopherol (Vitamin E) and Ascorbic Acid (Vitamin C) on the Renal Function and Histology of Adult Male Albino Wistar Rats with Sub-Acute Lead Acetate Exposure
}

\author{
Datonye Dennis Alasia1 ${ }^{(0)}$, Pedro Chimezie Emem-Chioma1, Sunday Ogbu Ojeka² \\ ${ }^{1}$ Department of Internal Medicine, College of Health Sciences, University of Port Harcourt, Port Harcourt, Nigeria \\ ${ }^{2}$ Department of Physiology, College of Health Sciences, University of Port Harcourt, Port Harcourt, Nigeria \\ Email: datonye.alasia@uniport.edu.ng
}

How to cite this paper: Alasia, D.D., Emem-Chioma, P.C. and Ojeka, S.O. (2020) An Evaluation of the Mitigating Effects of A-Tocopherol (Vitamin E) and Ascorbic Acid (Vitamin C) on the Renal Function and Histology of Adult Male Albino Wistar Rats with Sub-Acute Lead Acetate Exposure. Occupational Diseases and Environmental Medicine, 8, 35-49.

https://doi.org/10.4236/odem.2020.82003

Received: February 13, 2020

Accepted: March 16, 2020

Published: March 19, 2020

Copyright $\odot 2020$ by author(s) and Scientific Research Publishing Inc. This work is licensed under the Creative Commons Attribution International License (CC BY 4.0).

http://creativecommons.org/licenses/by/4.0/ (c) (i) Open Access

\begin{abstract}
Objectives: The aim of this study was to verify mitigating effects of the antioxidants $\alpha$ tocopherol (Vitamin E) and ascorbic acid (Vitamin C) on lead induced renal toxicity in adult male Wistar rats. Methods: A total of 36 mature male Wistar rats separated into 1 control group fed with rat feeds and water only and 3 study groups fed with $10 \mathrm{mg} / \mathrm{ml}$ of lead acetate, $10 \mathrm{mg} / \mathrm{ml}$ of lead acetate $+200 \mathrm{mg} / 2 \mathrm{ml}$ of vitamin C and $10 \mathrm{mg} / \mathrm{ml}$ of lead acetate $+100 \mathrm{mg} / 2 \mathrm{ml}$ of vitamin $\mathrm{E}$ respectively in addition to feds and water for 28 days were used. Blood samples were obtained for renal indices and the kidneys of all rats were harvested, weighed and prepared for histological examination. Result: The percentage weight gain was highest among control rats (20.70\%), followed by lead + vitamin E group (18.42\%), lead + vitamin C group (17.00\%) and the least amongst the lead group (9.50\%). The mean serum uric acid of $419.20 \pm$ $35.80 \mu \mathrm{mol} / \mathrm{L}$ in the lead treatment group was significantly higher than 395.50 $\pm 15.35 \mu \mathrm{mol} / \mathrm{L}, 393.30 \pm 14.16 \mu \mathrm{mol} / \mathrm{L}$ and $387.67 \pm 14.56 \mu \mathrm{mol} / \mathrm{L}$ in the lead + vitamin C group, lead + vitamin E group and controls respectively. The extent and proportion of renal tissue damage was higher in the lead-treated group and the commonest renal abnormalities observed were tubular and interstitial damage seen in $90.00 \%$ of rats in the lead-treated group compared to $75.00 \%$ and $60.00 \%$ in the lead + vitamin C and the lead + vitamin E groups respectively while the control rats had a normal histological appearance. Conclusions: The sub-acute administration of lead acetate may have inhibitory effect on growth of animals, and adversely affect renal function and histology with uric acid as
\end{abstract}


a more reliable marker of lead induced renal toxicity compared to urea and creatinine. The histologic parameters of tubulointerstitial abnormalities were also consistent with lead toxicity. Antioxidants were useful in reducing lead induced renal damage and growth inhibition with vitamin $\mathrm{E}$ producing a more potent effect compared to Vitamin C.

\section{Keywords}

Lead Acetate Toxicity, Oxidative Tissue Stress, Antioxidants Prevention

\section{Introduction}

Lead $(\mathrm{Pb})$ is a common environmental and occupational toxicant with adverse effects on multiple organ systems of humans and other animals even at low levels of exposure [1] [2] [3].

Oxidative stress has been shown to play a significant role in the process of $\mathrm{Pb}$ induced structural and functional organ damage [4] [5]. The effects of $\mathrm{Pb}$ include alterations in anti-oxidant defense systems and the generation of $\mathrm{Pb}$ induced reactive oxygen species that contribute to oxidative tissue stress, implicated in the pathogenesis of $\mathrm{Pb}$ induced hypertension, nephrotoxicity and damage in other organs [4] [5] [6] [7]. This pathogenic process therefore generates a potential role for antioxidants in the reduction of $\mathrm{Pb}$ induced tissue damage. To the extent that various studies have evaluated the role of antioxidants in preventing $\mathrm{Pb}$ induced tissue damage and even suggested a role for incorporation of antioxidants in the diets of highly lead exposed populations for prevention [8] [9] [10] [11]. The use of antioxidants in preventing $\mathrm{Pb}$ toxicity is supported by the outcome of various studies which have shown positive results. Onunkwor et al. [12] demonstrated a significant reversal of lead induced alterations in antioxidant systems of lead exposed artisans in Abeokuta, Nigeria using ascorbic acid (Vitamin C). The lead-induced inhibition of heme synthesis as measured by reduced activity of aminolevulinic acid dehydratase ( $\alpha$-ALAD) and increased erythrocyte protoporphyrin, has also been shown to be reversed with vitamin $\mathrm{C}$ administration by Ademuyiwa et al. [13]. Hanarfy et al. in Egypt [14] have also shown that the use of the antioxidant $\alpha$-tocopherol (Vitamin E) conferred protection and significantly reduced biochemical and structural renal system abnormalities in rats exposed to heavy metals including lead. The potential benefits of antioxidants in $\mathrm{Pb}$ exposed populations will therefore be most valuable in countries like Nigeria with documented high lead exposure burden, limited $\mathrm{Pb}$ exposure regulation and limited access to chelating therapy [15] [16] [17] [18]. These gaps are highlighted in the 2010 outbreak of acute lead poisoning in Zamfara state Nigeria which resulted in the death of many children. The key inadequacies included absence of chelating agents like calcium disodium ethylene diamine tetra-acetic acid (CaNa2EDTA), succimer (2,3-meso-dimercaptosuccinic acid) and D-penicillamine 
and dimercaptosuccinic acid (DMSA) which are the mainstay of treatment for persons with blood lead level (BLL) above $40 \mathrm{ug} / \mathrm{dl}$ which was prevalent in the populations; In addition to the inability to routinely monitor safety concerns which result from treatment with chelating agents [19] [20]. As a result research into the role of antioxidant in the prevention and alleviation of heavy metal toxicity is relevant in a country like Nigeria, as it offers a readily available, affordable and safe option in $\mathrm{Pb}$ exposed persons. It is on this proposition that this study therefore aims to appraise the structural and functional effects of sub-acute administration of lead acetate and the co-administration of the antioxidants $\alpha$ tocopherol (Vitamin E) and ascorbic acid (Vitamin C) on the kidney function and histology of adult male Wistar rats.

\section{Methodology}

\subsection{Study Design}

This was a cross sectional experimental study, involving a total of 36 mature male Wistar rats weighing 180 to $200 \mathrm{~g}$. The experimental animals were bred and housed in the animal House of the department of human physiology, University of Port Harcourt, Port Harcourt, Nigeria and allowed to acclimatize to laboratory conditions for one week at room temperature before start of the study with unrestricted access to water and standard diet. The study experiments were conducted in accordance with the Nigerian Health Research Ethics Committee Sub-Code for Research Involving Animals [21] while ethical clearance was obtained from the University of Port Harcourt Teaching Hospital, Ethics committee. The experimental animals were separated into 1 control and 3 test groups. The control group had 6 rats, while the 3 test groups had 10 rats each. The control group was fed with rat feeds and water only. Each rat in test group 1 Lead Only $(\mathrm{PbO})$ had $10 \mathrm{mg} / \mathrm{ml}$ of lead acetate in addition to rat feeds and water only daily for 28 days. Each rat in test group 2 Lead + Vitamin C (PbC) had $10 \mathrm{mg} / \mathrm{ml}$ of lead acetate + $200 \mathrm{mg} / 2 \mathrm{ml}$ of vitamin $\mathrm{C}$ and rat feeds and water daily for 28 days simultaneously, while rats in test group $3 \mathrm{Lead}+$ Vitamin $\mathrm{E}(\mathrm{PbE})$ had $10 \mathrm{mg} / \mathrm{ml}$ of lead acetate $+100 \mathrm{mg} / 2 \mathrm{ml}$ of vitamin $\mathrm{E}$ simultaneously with rat feeds and water, daily for 28 days.

\subsection{Data Analysis}

The weight of each rat was measured at the beginning and end of the study. Blood samples were obtained for kidney function indices (Serum Urea, Creatinine and Uric Acid). The kidneys of all rats were harvested, weighed and prepared for histological examination, after quick removal with immersion in 10\% formalin. Renal tissue were subsequently dehydrated, embedded in paraffin, sectioned at $4 \mathrm{~mm}$, stained with Haematoxylin and Oesin ( $\mathrm{HxE}$ ) method and evaluated by light microscopy at X400 magnification. Data was analysed using the statistical package software SPSS23 for windows. Comparisons of means were done using the ANOVA and independent $t$ test. Proportions were compared us- 
ing $\mathrm{Z}$ test and Chi-square test as appropriate. $\mathrm{p}$-value $\leq 0.05$ was considered as significant.

\section{Results}

\subsection{Body Weight of Animals}

The baseline and interval mean weight values and percentage weight changes are stated in Table 1. There were no significant differences between and within the mean weights at baseline by ANOVA. The study completion mean weight showed significant within mean differences with $\mathrm{p}=0.003$ between $\mathrm{PbC}$ and $\mathrm{PbE}$ groups by ANOVA. The percentage weight gain was highest among control rats (20.92\%), followed by $\mathrm{PbE}(18.42 \%), \mathrm{PbC}(17.00 \%)$ and the least amongst the lead group (9.50\%). The comparison of proportions showed significant differences between $\mathrm{Pb}$ and $\mathrm{PbE}$ with $\mathrm{p}=0.02$.

\subsection{Kidney Function Parameters}

The renal function and renal weight parameters for the study animals are as shown in Table 2. The serum urea for controls was $3.55 \pm 0.23 \mathrm{mmol} / \mathrm{L} \mathrm{com-}$ pared to $3.39 \pm 0.23 \mathrm{mmol} / \mathrm{L}$ for $\mathrm{Pb}$ Only treated group; $3.25 \pm 0.21 \mathrm{mmol} / \mathrm{L}$ for $\mathrm{PbC}$ and $3.33 \pm 0.21$ for $\mathrm{PbE}$ group. There was no statistically significant difference between and within the means with ANOVA and independent $t$ test. The mean serum creatinine for the control group was $75.00 \mu \mathrm{mol} / \mathrm{L} \pm 4.34$, compared to $73.50 \pm 2.92 \mu \mathrm{mol} / \mathrm{L}$ for $\mathrm{Pb}$ Only; $72.50 \pm 4.78 \mu \mathrm{mol} / \mathrm{l}$ for $\mathrm{PbC}$ and $74.50 \pm$ $2.92 \mu \mathrm{mol} / \mathrm{L}$ for $\mathrm{PbE}$, with no statistically significant difference with ANOVA and comparisons of means with $\mathrm{t}$ test. The mean serum uric acid for the $\mathrm{Pb}$ Only group was $419.20 \pm 35.80 \mu \mathrm{mol} / \mathrm{L}$, compared to $395.50 \pm 15.35 \mu \mathrm{mol}$ for $\mathrm{PbC}$ group, $393.30 \pm 14.16 \mu \mathrm{mol} / \mathrm{L}$ for $\mathrm{PbE}$ group $(\mathrm{p}=0.04)$ and $387.67 \pm 14.56$ $\mu \mathrm{mol} / \mathrm{L}$, for the control group $(\mathrm{p}=0.03)$ with statistical significance as shown with independent $t$ test and ANOVA.

\subsection{Morphologic and Histological Analysis of Kidneys}

The weight of the kidneys was $0.63 \pm 0.11 \mathrm{~g}$ in the control group, $0.64 \pm 0.10 \mathrm{~g}$ for $\mathrm{Pb}$ Only group, $0.65 \pm 0.07 \mathrm{~g}$ for $\mathrm{PbC}$ group and $0.66 \pm 0.09 \mathrm{~g}$ for $\mathrm{PbE}$ group, as shown in Table 2. There was no significant difference in the means with ANOVA and $\mathrm{t}$ test.

The commonest renal abnormalities observed were tubular and interstitial damage seen in $90.00 \%$ of rats in the lead-treated group compared to $75.00 \%$ and $60.00 \%$ in the $\mathrm{PbC}$ and $\mathrm{PbE}$ groups respectively. The comparison of proportions showed significant differences between $\mathrm{PbC}$ and $\mathrm{PbE}(\mathrm{p}=0.02)$. The other histological abnormalities were cortical, interstitial and glomerular cellular infiltrates in a frequency of $20.00 \%$ in the $\mathrm{Pb}$ Only and $\mathrm{PbC}$ groups and $10.00 \%$, in the PbE. The control rats had a normal histological appearance. The histological appearance of the study animals is shown in Figures 1-5. 
Table 1. Baseline mean weight, interval mean weight and percentage weight change in study animals.

\begin{tabular}{|c|c|c|c|c|c|}
\hline Study Group & $\begin{array}{c}\text { Baseline weight } \\
\text { Mean } \pm \text { SD (grams) }\end{array}$ & $\begin{array}{c}\text { Interval weight } \\
\text { Mean } \pm \text { SD (grams) }\end{array}$ & $\mathrm{p}$ value & $\%$ weight gain & $\mathrm{p}$ value \\
\hline Control group (normal feed) & $203.33 \pm 29.42 \mathrm{~g}$ & $245.83 \pm 51.03 \mathrm{~g}$ & & $20.92 \%$ & \\
\hline Group-Lead only $(\mathrm{PbO})$ & $210.00 \pm 10.54 \mathrm{~g}$ & $230.00 \pm 34.96 \mathrm{~g}$ & & $9.52 \%$ & \\
\hline Group-lead + ascorbic acid (PbC) & $200.00 \pm 0.001 \mathrm{~g}$ & $234.00 \pm 23.90$ & & $17.00 \%$ & \\
\hline Group-lead $+\alpha$-tocopherol $(\mathrm{PbE})$ & $190.00 \pm 10.54 \mathrm{~g}$ & $225.00 \pm 26.23$ & 0.003 & $18.42 \%$ & 0.02 \\
\hline NS $=$ Not Significant & NS & & & & \\
\hline
\end{tabular}

Table 2. Renal function parameters and renal weight of study animals.

\begin{tabular}{|c|c|c|c|c|}
\hline & Controls & $\mathrm{Pb}$ Only Group & PbC Group & PbE Group \\
\hline \multicolumn{5}{|l|}{ Parameters } \\
\hline Serum Urea (mmol/L) & $3.55 \pm 0.23$ & $3.39 \pm 0.23$ & $3.25 \pm 0.21$ & $3.33 \pm 0.21$ \\
\hline Serum Creatinine $(\mu \mathrm{mol} / \mathrm{L})$ & $75.00 \pm 4.34$ & $73.50 \pm 2.92 \mu \mathrm{mol}$ & $72.50 \pm 4.78 \mu \mathrm{mol} / \mathrm{L}$ & $74.50 \pm 2.92 \mu \mathrm{mol}$ \\
\hline Serum Uric Acid $(\mu \mathrm{mol} / \mathrm{L})$ & $387.67 \pm 14.56$ & $\begin{array}{c}419.20 \pm 35.80 \\
(p=0.03)\end{array}$ & $395.50 \pm 15.35$ & $\begin{array}{c}393.30 \pm 14.16 \\
(p=0.04)\end{array}$ \\
\hline Renal weight grams (Rt and Lt) & $0.63 \pm 0.11$ & $0.64 \pm 0.10$ & $0.65 \pm 0.07$ & $0.66 \pm 0.09$ \\
\hline
\end{tabular}

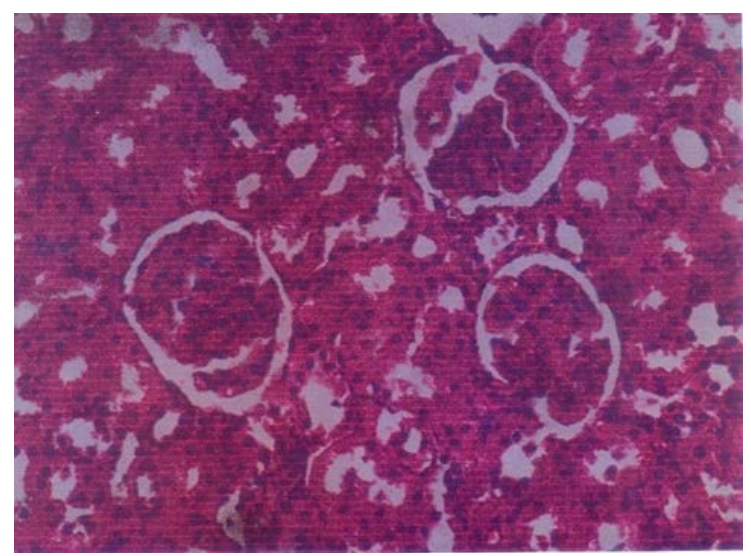

Figure 1. Showing normal glomeruli, tubules and interstitium of the kidney in the control group (H\&E Stain ( $\times 400$ Magnification)).

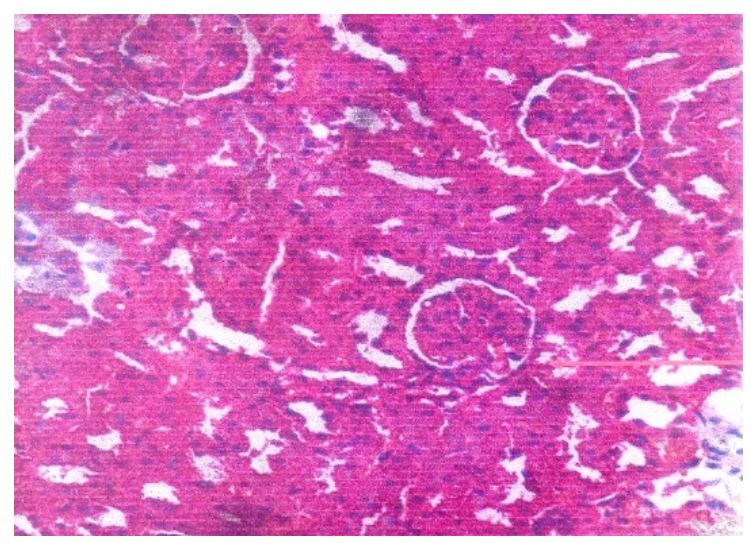

Figure 2. Showing degeneration of tubules and tubular cast in the lead only group (H\&E Stain $(\times 400$ Magnification)). 


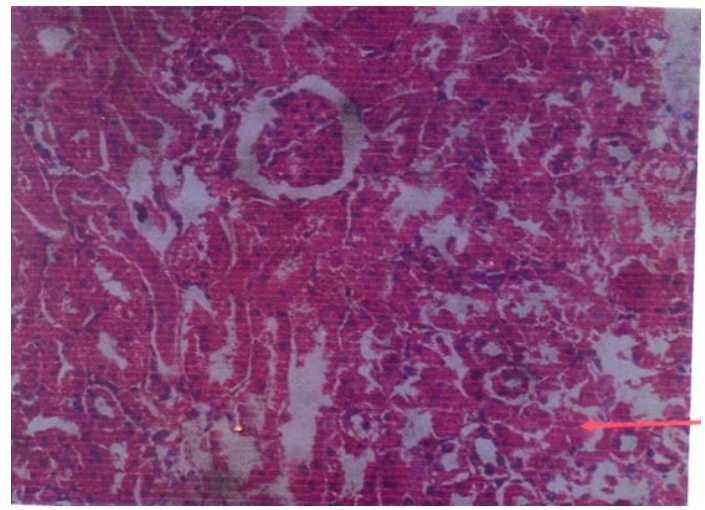

Figure 3. Showing glomeruli with hyper cellularity indicative of either inflammation and mesangial proliferation in the lead only group (H\&E Stain ( $\times 400$ Magnification)).

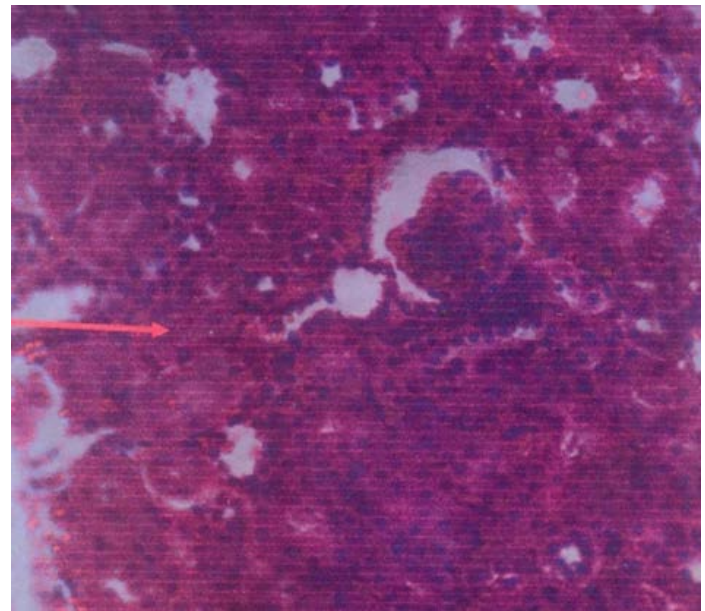

Figure 4. Showing regeneration of the tubules after injury in the lead plus vitamin C group (H\&E Stain ( $\times 400$ Magnification)).

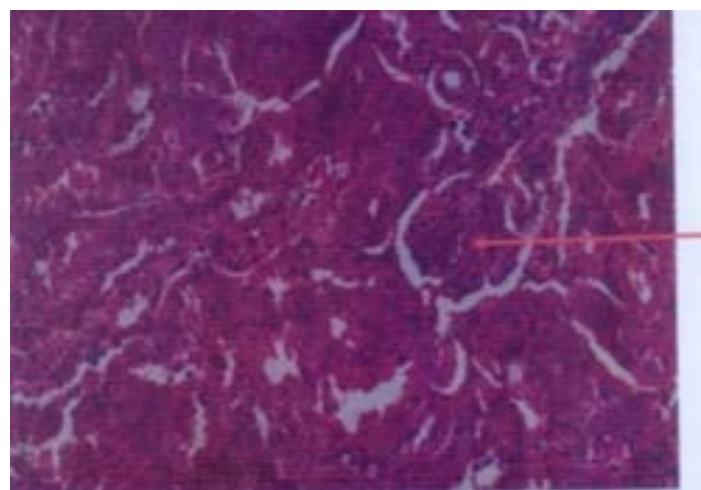

Figure 5. Showing regeneration of the tubules in the lead plus vitamin E group (H\&E Stain $(\times 400$ Magnification))

\section{Discussion}

Lead toxicity resulting from acute, sub-acute or chronic exposure is known to have harmful effects as a consequence of oxidative stress and tissue injury [4] [5] 
[8]. Therefore the use of anti-oxidants is propositioned as a cost effective strategy for the mitigation and prevention of lead induced tissue injury especially in settings where lead exposure is common and adequate care for heavy lead exposure is not readily available [8] [9] [10] [11].

This study set out to evaluate the comparative mitigating effect of two common anti-oxidant compounds, ascorbic acid (Vitamin C) and $\alpha$-tocopherol (Vitamin E) on the renal biochemical and histologic parameters of adult male Wistar rats.

The results of the study indicate that the sub-acute lead acetate toxicity has inhibitory effect on growth as the percentage weight gain was lowest in lead-treated group with 9.50\%, compared to the control group, lead + vitamin E group and lead + vitamin C group with $20.70 \%, 18.42 \%$ and $17.00 \%$ growth rates respectively. The findings also support the protective effect of the anti-oxidants ascorbic acid (Vitamin C) and $\alpha$-tocopherol (Vitamin E).

The results of this study are comparable with the findings of Ibrahim et al. [22] in a study of lead effects on albino rats with control rats achieving almost $100 \%$ weight gain compared to lead acetate fed rats with $60 \%$ weight gain. Ponce-Canchihuamán et al. [23] also reported similar weight trend pattern comparable to the results of this study with significantly reduced weight gain in lead group compared to the lead and spiriluna and control group, during an assessment of the effects of the antioxidant spiriluna in lead acetate fed rats. Ezejiofor et al. [24] in a study of the antioxidant effect of Costus afer (CA) in lead fed rats documented that the total weight of $114.52 \pm 11.3$ grams in lead fed rats was lower than 130.9.34 grams in rats with $1500 \mathrm{mg}$ dose CA respectively. These findings support the mitigating effects of antioxidants on lead induced weight loss in lead exposed animals.

Three biochemical parameters of renal function assessed in this study were urea, creatinine and uric acid. The comparison of urea and creatinine levels among the different experimental groups did not show any significant differences, while uric acid levels were significantly higher in the lead acetate treated group, compared to the controls and lead and vitamin $\mathrm{E}$ and lead and vitamin $\mathrm{C}$ groups respectively.

In comparison with findings from other studies, Salem et al. [25] in a study of the protective effects of garlic on lead exposed rats documented significantly higher urea values in lead exposed rats of $34.6 \pm 3.5 \mathrm{mg} / \mathrm{dl}$ compared to $24.5 \pm$ $2.6 \mathrm{mg} / \mathrm{dl}$ and $22.2 \pm 2.3 \mathrm{mg} / \mathrm{dl}$ in lead plus garlic fed rats and controls in contrast with the findings of this study; with urea values of $3.55 \pm 0.23 \mathrm{mmol} / \mathrm{L}, 3.39$ $\pm 0.23 \mathrm{mmol} / \mathrm{L}, 3.25 \pm 0.21 \mathrm{mmol} / \mathrm{L}$ and $3.33 \pm 0.21$ in controls, lead treated group, lead + vitamin C group and lead + vitamin E group respectively.

Al-Attar et al. [26], evaluated the protective effect of vitamin $\mathrm{E}$ in heavy metals exposed rat's and documented significant differences in values of urea in lead exposed rats compared to rats on lead plus vitamin $\mathrm{E}$ and controls with the following respective values $25.45 \pm 3.09 \mathrm{mg} / \mathrm{dl}, 14.88 \pm 2.46 \mathrm{mg} / \mathrm{dl}$ and $13.95 \pm 1.38$ $\mathrm{mg} / \mathrm{dl}$, in contrast with the findings on this study. 
Hanafy et al. [14] also documented increase urea of 77\% from baseline in lead treated rats compared to $17 \%$ in controls also contrasting with the findings of our study.

In comparable pattern with the findings of this study, Andjelkovic et al. [27], in a study of acute heavy metal effect on renal, hepatic and blood parameters in rats also documented significantly higher urea of $10.72 \pm 1.02 \mathrm{mmol} / \mathrm{l}$ in the controls compared to $8.76 \pm 1.12 \mathrm{mmol} / \mathrm{l}$ and $9.08 \pm 1.13 \mathrm{mmol} / \mathrm{l}$ in lead only and lead plus cadmium exposed rats respectively. Similarly Ezejiofor et al. [24] studied the antioxidant protective effects of Costusafer (CA) extract and reported no significant difference in urea values in the lead only group of $1.1 \pm 0.1$ $\mathrm{mg} / \mathrm{dl}$ compared $1.2 \pm 0.03 \mathrm{mg} / \mathrm{dl}$ in the lead plus $1500 \mathrm{mg}$ CA group.

The trend of creatinine reported in the study by Salem et al. [25] showed significant differences in values with higher creatinine values of $1.9 \pm 0.14 \mathrm{mg} / \mathrm{dl}$ in lead exposed animals compared with $1.1 \pm 0.09 \mathrm{mg} / \mathrm{dl}$ in the garlic plus lead group and $0.90 \pm 0.05 \mathrm{mg} / \mathrm{dl}$ in the controls, contrasting with this study findings with insignificantly higher creatinine in the controls of $75.00 \mu \mathrm{mol} / \mathrm{L} \pm 4.34 \mathrm{com}$ pared to $73.50 \pm 2.92 \mu \mathrm{mol} / \mathrm{L}$ for lead-treated group, $72.50 \pm 4.78 \mu \mathrm{mol} / \mathrm{l}$ for lead + vitamin $\mathrm{C}$ and $74.50 \pm 2.92 \mu \mathrm{mol} / \mathrm{L}$ for lead + vitamin E group. Al Altar et al. [27] reported higher creatinine of $0.93 \pm 0.05 \mathrm{mg} / \mathrm{dl}$ in lead group compared to $0.46 \pm 0.05 \mathrm{mg} / \mathrm{dl}$, and $0.37 \pm 0.03 \mathrm{mg} / \mathrm{dl}$ in the lead and vitamin $\mathrm{E}$ and control groups respectively. Andjelkovic et al. [27], also reported a significant and higher creatinine values in lead fed group $43.40(41.4$ - 46.5) $\mu \mathrm{mol} / \mathrm{l}$ compared to 42.45 (39.5-43.5) $\mu \mathrm{mol} / 1$ in controls; while Hanafy et al. [14] reported a $24 \%$ increase in baseline creatinine in lead group compared to $7 \%$ in the lead plus vitamin $\mathrm{E}$ protected group.

The trend of insignificant differences in serum creatinine in our study has also been documented in other studies. A study by Ishaik et al. [28] which used lycophene as the antioxidant did not find significant difference between serum creatinine value of $18.0 \pm 4.6 \mathrm{mg} / \mathrm{dl}$ in lead only group compared to $15.1 \pm 3.5$ $\mathrm{mg} / \mathrm{dl}$ in lead plus lycopene group and $10.0 \pm 2.3 \mathrm{mg} / \mathrm{dl}$ in controls. Odigie et al. [29] in a low level lead exposure study did not report significant differences in serum creatinine value of $57.8 \pm 7.5 \mu \mathrm{mol} / \mathrm{L}$ in lead exposed rats compared to controls with $49.0 \pm 2.7 \mu \mathrm{mol} / \mathrm{L}$. Ezejiofor et al. [24] using CA as the protective antioxidant also did not find any significant difference in creatinine values of $178 \pm 3.0 \mu \mathrm{mol} / \mathrm{L}$ in the lead only group compared to $175 \pm 1.5 \mu \mathrm{mol} / \mathrm{l}$ in the lead plus $1500 \mathrm{mg}$ CA group.

The variance in the outcome of this study and comparator studies could be due to varied weights of animals which may have an influence on creatinine and urea values which are related to weight and muscle bulk. In addition other factors like the varying dose of lead used in the studies and the diverse level of lead exposure from acute, sub-acute and chronic may also account for the differences as the study duration in the work of Al-Attar et al. [26] was 7 weeks, 10 weeks for the study by Salem et al. [25], acute low level exposure for below 2 weeks by Ishiak et al. [28], 1 week by Andjelkovic et al. [27] and chronic low exposure of 3 
months by Odigie et al. [29]. In addition the differing results could also be explained by the recognition that serum urea and creatinine are less reliable markers of lead induced kidney damage as indicated by other reports [30] [31] [32] and the sample size limitations due to the ethical limitations for large animal sample population.

The serum uric acid of $419.20 \pm 35.80 \mu \mathrm{mol} / \mathrm{L}$ recorded in the lead treatment group in this study was significantly higher than the respective values of 395.50 $\pm 15.35 \mu \mathrm{mol} / \mathrm{L}, 393.30 \pm 14.16 \mu \mathrm{mol} / \mathrm{L}$ and $387.67 \pm 14.56 \mu \mathrm{mol} / \mathrm{L}$ for the lead + vitamin $\mathrm{C}$ group, lead + vitamin $\mathrm{E}$ and control respectively. The results are consistent with that of other studies as Salem et al. [25] reported significantly higher uric acid values of $3.24 \pm 0.28 \mathrm{mg} / \mathrm{dl}$ in lead only group compared to $1.92 \pm 0.16$ $\mathrm{mg} / \mathrm{dl}$ and $1.85 \pm 0.17 \mathrm{mg} / \mathrm{dl}$ in the lead plus garlic and control group respectively in line with the findings of this study. Al-Attar et al. [26] also reported higher urate of $3.09 \pm 0.31 \mathrm{mg} / \mathrm{dl}$ in lead group compared to $1.83 \pm 0.23 \mathrm{mg} / \mathrm{dl}$ and $1.88 \pm 0.13 \mathrm{mg} / \mathrm{dl}$ in the lead plus vitamin e and controls groups respectively. These findings indicate that irrespective of the duration and level of lead exposure uric acid elevation is an early, consistent and more reliable marker of lead induced kidney damage when compared to the other renal function parameters. The findings also indicate a mitigative effect of antioxidants which include vitamin $\mathrm{C}$ and $\mathrm{E}$ on lead induced renal damage exemplified by elevated uric acid.

Increase in urate levels is a known association of lead exposure which occurs in both acute and chronic exposure with oxidative stress and impairment of nitric oxide as a mechanism and consequence [31] [32] [33] [34] [35]. In addition the elevation of urate in lead exposure is also known to occur at low doses of lead exposure and even when kidney disease or damage is still subclinical [31] [32] [33]. This may explain the finding of significant change in uric acid in this study when compared to the other renal biochemical parameters. In addition the contribution of oxidative mechanisms in this process also supports the role of antioxidant use in uric acid reduction in lead exposed animals as seen in this and other studies [25] [26].

The renal organ weight and histologic pattern was also used in evaluating the effect of lead on the kidneys and the mitigating effect of antioxidants. The study findings indicate that the weight of the kidneys was not significantly different between the control $(0.63 \pm 0.11 \mathrm{~g})$ and the various treatment groups $\mathrm{Pb}$ Only $0.64 \pm 0.10 \mathrm{~g}$; $\mathrm{PbC} 0.65 \pm 0.07 \mathrm{~g}$; and $\mathrm{PbE}$ group $0.66 \pm 0.09$, as shown in Table 2 , though the renal weight in the control and antioxidant groups were marginally higher. These findings are similar with the findings of Odigie et al. [29] who reported insignificant changes in the right and left renal weight of lead fed rats of $0.57 \pm 0.05 \mathrm{~g}$ and $0.57 \pm 0.06 \mathrm{~g}$ respectively compared to $0.62 \pm 0.10 \mathrm{~g}$ and 0.63 $\pm 0.08 \mathrm{~g}$ in controls respectively. Another study by Ibrahim et al. [22] did not find significant differences in the organ weight of controls which was $2.5 \pm 0.13$ g compared to lead exposed animals with $2.99 \pm 0.81$ g. However significant differences were observed in organ body weight ratio in controls of $0.68 \pm 10$ com- 
pared to a higher ratio of $1.00 \pm 00$ in exposed animals indicating an impact of lead on the kidney. Ezejiofor et al. [24] documented that the renal weight of the rats in the lead group of $0.77 \pm 0.01 \mathrm{~g}$ was lower than that of rats with lead plus antioxidant CA of $0.80 \pm 0.00$ at all doses of CA. They also found a higher organ to body weight ratio 0.67 in lead only rats compared to 0.31 in lead plus CA fed rats. Salem et al. [25] also documented lower kidney weight in the lead exposed groups of $1.6 \pm 0.2 \mathrm{~g}$ compared with $2.1 \pm 0.4 \mathrm{~g}$ and $2.0 \pm 0.3 \mathrm{~g}$ in controls and the lead plus garlic group respectively indicating a significant impact of antioxidant on lead induced reduction of renal weight and protection from the antioxidant garlic.

These findings show that renal weight is reduced in lead exposed animals. This finding is characteristic of lead nephrotoxicity which manifests with uniformly contracted kidneys in the presence of excessive lead absorption [31] [32]. The findings also show that the application of antioxidants can mitigate this effect.

The key histologic findings in acute lead nephrotoxicity are the reversible presence of acid-fast lead induced nuclear inclusion bodies which are lead-protein complexes in the proximal tubular cells [32]. In chronic lead nephrotoxicity the kidneys macroscopically appear contracted and have a granular surface, with the cut surface showing general loss of cortical tissue, corticomedullary demarcation, and vascular markings with intact but small pyramids [31] [32]. The histologic hallmark is a chronic acellular interstitial nephritis comprising of coexisting dilated and alternate atrophic tubules [31] [32]. In addition a large proportion of glomeruli are lost without leaving a trace, with some coexisting periglomerular fibrosis indicating that lead kidney disease is largely a tubulointerstitial disease [31] [32].

The histological analysis of rats kidneys in this study showed that renal tubular and interstitial damage were the major abnormalities observed in this study as shown in Figures 2-5; with a significantly higher extent and proportion of renal tissue damage of $90 \%$ observed in the lead-treated group, compared to $75.00 \%$ and $60.00 \%$ in the lead + vitamin C and the lead + vitamin E groups respectively. The other histological abnormalities were cortical, interstitial and glomerular cellular infiltrates in a frequency of $20.00 \%$ in the lead only and lead and vitamin C group and $10.00 \%$, the lead and vitamin $\mathrm{E}$ treated group. The morphologic and histologic findings of this study are distinctive off sub-acute lead nephrotoxicity [31] [32]. The results also show significant protective effect of vitamin $\mathrm{C}$ and vitamin $\mathrm{E}$ on lead induced kidney damage with vitamin $\mathrm{E}$ having a more protective effect. The histologic pattern observed in this study are comparable with the findings of other studies by Odigie et al. [29] who reported minimal interstitial changes in low level chronic exposure and Hanafy et al. [14] who found dense renal tubular cells, glomerular shrinkage and widening of capsular space typical with lead nephrotoxicity [31] [32] with vitamin E providing a significant protective effect. In like pattern Al-Attar et al. [26] also reported renal tubular dilatations with congestion of blood vessels with hemorrhage and dege- 
neration of renal corpuscles and a significant protective effect from vitamin $\mathrm{E}$ administration in line with the findings of this study.

The outcome of this study and other studies on the protective effect of antioxidant against lead toxicity effect in experimental animals gives justification to the application of antioxidants for reduction of lead toxicity damage in humans. This assertion is supported by the outcome of cross sectional studies across Nigeria and the globe as demonstrated by the significant reversal of lead induced alterations in antioxidant systems of lead exposed artisans in Abeokuta Nigeria using ascorbic acid by Onunkwor et al. [12] and the reversal lead-induced inhibition of heme synthesis as measured by reduced activity of aminole-vulinic acid dehydratase ( $\alpha$-ALAD) and increased erythrocyte protoporphyrin, with vitamin $\mathrm{C}$ administration by Ademuyiwa et al. [13]. Akinhami et al. [36] also showed significant ameliorative effects of vitamin $\mathrm{C}$ in a spectrum of lead exposed workers using $400 \mathrm{mg}$ of vitamin C supplementation which resulted in 51\%, 33\%, 13\% and $28 \%$ reduction of blood $\mathrm{Pb}$ in polyurethrane workers, auto mechanics and allied workers, motor terminus workers and controls respectively. There was also evidence of antioxidant effect documented by the reduction in glutathione (GSH) and increased level of plasma aminolevulinic acid (ALA). Esimai et al. [37] also documented that Vitamin $C$ reduced the urinary excretion of lead in a group of primary school children in south west Nigeria while Dawson et al. [38] in a study of the general population in the USA also established that daily supplementation with $1000 \mathrm{mg}$ of ascorbic acid results in a significant decrease of blood-lead levels associated with the general population and postulates that ascorbic acid supplementation may provide an economical and convenient method of reducing blood-lead levels.

In addition various reviews [9] [39] [40] [41] and other cross sectional animal studies [42] [43] have also documented the role of vitamin E as a significant preventive and adjunct therapy for lead exposure and toxicity. Patra et al. [42] in a study of the ameliorative effects of antioxidant (ascorbic acid, $\alpha$ tocopherol or l-methionine) alone and antioxidant ( $\alpha$ tocopherol) plus a conventional chelator (CaNa2 EDTA) established significant reduction of lead toxic effects with the use of vitamin E while Elshelby et al. [43] in a study of the protective effects of vitamin E supplementation in fish (in Oreochromis niloticus) found that it reduced the accumulation of lead in fish muscle and prevented its negative impact on growth when compared with controls as dietary vitamin E supplementation reduced lead concentrations in muscles and increased GH levels in serums of $\mathrm{Pb}$ treated fishes.

It is observed that there are more studies on the use of vitamin $\mathrm{C}$ for lead toxicity mitigation when compared to vitamin E probably due to safety concerns relating to solubility. It is also recommended that co-administration of different groups of antioxidants molecules may confer greater benefit due to combined antioxidant and chelation functions thus resulting in more effective reduction of oxidative stress mediated by lead toxicity [10] [40]. The non-assessment of co-administration of vitamin $\mathrm{E}$ and vitamin $\mathrm{C}$ in this study is a limitation which can be addressed in further studies. 


\section{Conclusion}

In conclusion, this study corroborates the outcome of other studies and reviews which have established the utility of the antioxidants vitamin $\mathrm{C}$ and $\mathrm{E}$ in the prevention and mitigation of the effects of lead exposure and toxicity especially on renal structure and function. It is recommended that these antioxidants are utilized as a preventive strategy in a country like Nigeria where lead exposure is prevalent and access to chelation therapy is not routine. It also strengthens the recommendation for longitudinal studies on the utility of these antioxidants in the prevention of low level chronic lead exposure in the human population.

\section{Conflicts of Interest}

The authors declare no conflicts of interest regarding the publication of this paper.

\section{References}

[1] Fewtrell, L., Kautmann, R. and Pruss-Ustun, A. (2003) Lead: Assessing the Environmental Burden of Disease at National and Local Levels. WHO (WHO Environmental Burden of Disease Series No. 2).

[2] Tong, S., Von Schirnding, Y.E. and Prapamontol, T. (2000) Environmental Lead Exposure: A Public Health Problem of Global Dimensions: Theme Papers. Bulletin of the WHO, 78, 1068-1077.

[3] Landrigan, P.J. (1990) current Issues in the Epidemiology and Toxicology of Occupational Exposure to Lead. Environmental Health Perspective, 89, 61-66. https://doi.org/10.1289/ehp.908961

[4] Ercal, N., Gurer-Orhan, H. and Aykin-Burns, N. (2001) Toxic Metals and Oxidative Stress. Part1. Mechanism Involved in Metal-Induced Oxidative Damage. Current Topics in Medicinal Chemistry, 1, 529-539. https://doi.org/10.2174/1568026013394831

[5] Gurer-Orhan, H., Sabir, H.U. and Ozgunes, H. (2004) Correlation between Clinical Indicators of Lead Poisoning and Oxidative Stress Parameters in Controls and Lead-Exposed Workers. Toxicology, 195, 147-154. https://doi.org/10.1016/j.tox.2003.09.009

[6] Kopp, S.J., Barron, J.T. and Tow, J.P. (1988) Cardiovascular Actions of Lead and Relationship to Hypertension: A Review. Environmental Health Perspective, 78, 91-99. https://doi.org/10.1289/ehp.887891

[7] Vaziri, N.D. (2008) Mechanisms of Lead-Induced Hypertension and Cardiovascular Disease. American Journal of Physiology-Heart and Circulatory Physiology, 295, H454-H465. https://doi.org/10.1152/ajpheart.00158.2008

[8] Lamidi, I.Y. and Akefe, I.O. (2017) Mitigate Effects of Antioxidants in Lead Toxicity. Clinical Pharmacology \& Toxicology Journal, 1, 3.

[9] Gurer, H. and Ercal, N. (2000) Can Antioxidants Be Beneficial in the Treatment of Lead Poisoning? Free Radical Biology and Medicine; 29, 927-945. https://doi.org/10.1016/S0891-5849(00)00413-5

[10] Patrick, L. (2006) Lead Toxicity Part II: The Role of Free Radical Damage and the Use of Antioxidants in the Pathology and Treatment of Lead Toxicity. Alternative Medicine Review, 11, 114-127. 
[11] Kordas, K. (2017) The "Lead Diet": Can Dietary Approaches Prevent or Treat Lead Exposure? The Journal of Paediatrics, 185, 224-231. https://doi.org/10.1016/j.jpeds.2017.01.069

[12] Onunkwor, B., Dosumu, O., Odukoya, O.O., Arowolo, T. and Ademuyiwa, O. (2004) Biomarkers of Lead Exposure in Petrol Station Attendants and Auto-Mechanics in Abeokuta, Nigeria: Effects of 2-Week Ascorbic Acid Supplementation. Environmental Toxicology and Pharmacology, 17, 169-176.

https://doi.org/10.1016/j.etap.2004.04.003

[13] Ademuyiwa, O., Ugbaja, R.N., Ojo, D.A., Owoigbe, A.O. and Adeokun, S.E. (2005) Reversal of Aminolevulinic Acid Dehydratase (ALAD) Inhibition and Reduction of Erythrocyte Protoporphyrin Levels by Vitamin C in Occupational Lead Exposure in Abeokuta, Nigeria. Environmental Toxicology and Pharmacology, 20, 404-411. https://doi.org/10.1016/j.etap.2005.04.002

[14] Hanafy, S. and Soltan, M.E. (2004) Effects of Vitamin E Pre-Treatment on Subacute Toxicity of Mixture of $\mathrm{Co}, \mathrm{Pb}$, and $\mathrm{Hg}$ Nitrate-Induced Nephrotoxicity in Rats. Environmental Toxicology and Pharmacology, 17, 159-167. https://doi.org/10.1016/j.etap.2004.04.006

[15] Alasia, D.D. (2019) Lead Exposure Risk and Toxicity: A Review of Situational Trends in Nigeria. Journal of Environment Pollution and Human Health, 7, 78-99.

[16] Adebamowo, E.O., Agbede, O.A., Sridhar, M.K.C. and Adebamowo, C.A. (2006) An Examination of Knowledge, Attitudes and Practices Related to Lead Exposure in South Western Nigeria. BMC Public Health, 6, 82. https://doi.org/10.1186/1471-2458-6-82

[17] Orisakwe, O.E. (2009) Environmental Pollution and Blood Lead Levels in Nigeria: Who Is Un-Exposed? International Journal of Occupational and Environmental Health, 15, 315-317. https://doi.org/10.1179/oeh.2009.15.3.315

[18] Adeniyi, F.A. and Anetor, J.I. (1999) Lead-Poisoning in Two Distant States of Nigeria: An Indication of the Real Size of the Problem. African Journal of Medicine and Medical Sciences, 28, 107-112.

[19] Ajumobi, O.O., Tsofo, A., Yango, M., Aworh, K.M., Anagbogu, I.N., Mohammed, A., et al. (2014) High Concentration of Blood Lead Levels among Young Children in Bagega Community, Zamfara-Nigeria and the Potential Risk Factor. Pan African Medical Journal, 18, 14. https://doi.org/10.11604/pamj.supp.2014.18.1.4264

[20] Dooyema, C.A., Neri, A., Lo, Y.-C., Durant, J., Dargan, P.I., Swarthout, T. and Biya, O. (2010) Outbreak of Fatal Childhood Lead Poisoning Related to Artisanal Gold Mining in Northwestern Nigeria. Environmental Health Perspectives, 120, 601-607. https://doi.org/10.1289/ehp.1103965

[21] Federal Ministry of Health (2014) National Health Research Ethics Committee of Nigeria. Sub-Code For Search Involving Animals.

http://nhrec.net/download-nchre/

[22] Ibrahim, N.M., Eweis, E.A., El-Beltagi, H.S. and Abdel-Mobdya, Y.E. (2012) Effect of Lead Acetate Toxicity on Experimental Male Albino Rat. Asian Pacific Journal of Tropical Biomedicine, 2, 41-46. https://doi.org/10.1016/S2221-1691(11)60187-1

[23] Ponce-Canchihuamán, P.C., Pérez-Méndez, O., Hernández-Muñoz, R., Torres-Durán, P.V. and Juárez-Oropeza, M.A. (2010) Protective Effects of Spirulina Maxima on Hyperlipidemia and Oxidative-Stress Induced by Lead Acetate in the Liver and Kidney. Lipids in Health and Disease, 9, 35. https://doi.org/10.1186/1476-511X-9-35

[24] Ezejiofor, A.N. and Orisakwe, O.E. (2019) Nephroprotective Effect of Costusafer on 
Lead Induced Kidney Damage in Albino Rats. International Journal of Physiology, Pathophysiology and Pharmacology, 11, 36-44.

[25] Salem, N.A. and Salem, E.A. (2016) Protective Antioxidant Efficacy of Garlic against Lead Induced Renal and Testicular Toxicity in Adult Male Rats. Journal of Heavy Metal Toxicity and Diseases, 1, 15-21.

[26] Al-Attar, A.M. (2011) Antioxidant Effect of Vitamin E Treatment on Some Heavy Metals-Induced Renal and Testicular Injuries in Male Mice. Saudi Journal of Biological Sciences, 18, 63-72. https://doi.org/10.1016/j.sjbs.2010.10.004

[27] Andjelkovic, M., Djordjevic, A.B., Antonijevic, E., Antonijevic, B., Stanic, M., Kotur-Stevuljevic, J., et al. (2019) Toxic Effect of Acute Cadmium and Lead Exposure in Rat Blood, Liver, and Kidney. International Journal of Environmental Research and Public Health, 16, 274. https://doi.org/10.3390/ijerph16020274

[28] Ishiaq, O., Adeagbo, A.G. and Nta, H. (2011) Effect of a Natural Antioxidant Fruit-Tomatoes (Lycoperscionesculentium) as a Potent Nephroprotective Agent in Lead Induced Nephrotoxicity in Rat. Journal of Pharmacognosy and Phytotherapy, 3, 63-66.

[29] Odigie, I.P., Ladipo, C.O., Ettarh, R.R. and Izegbu, M.C. (2004) Effect of Chronic Exposure to Low Levels of Lead on Renal Function and Renal Ultrastructure in SD Rats. Nigerian Journal of Physiological Sciences, 19, 27-32. https://doi.org/10.4314/njps.v19i1.32632

[30] Alasia, D.D. (2010) Lead Nephropathy: Revisiting an Overlooked Cause of Kidney Disease. Nephrology Reviews, 2, e8. https://doi.org/10.4081/nr.2010.e8

[31] Benneth, W.M. (1985) Lead Nephropathy. Kidney International, 28, 212-220. https://doi.org/10.1038/ki.1985.143

[32] Kathuria, P. (2019) Lead Nephropathy. https://emedicine.medscape.com/article/242605-overview\#a13

[33] Lin, J.L., Tan, D.T., Ho, H.H. and Yu, C.C. (2002) Environmental Lead Exposure and Urate Excretion in the General Population. The American Journal of Medicine, 113, 563-568. https://doi.org/10.1016/S0002-9343(02)01296-2

[34] Lin, J.L., Yu, C.C., Lin-Tan, D.T. and Ho, H.H. (2001) Lead Chelation Therapy and Urate Excretion in Patients with Chronic Renal Diseases and Gout. Kidney International, 60, 266-271. https://doi.org/10.1046/j.1523-1755.2001.00795.x

[35] Giordano, C., Karasik, O., King-Morris, K. and Asma, A. (2015) Uric Acid as a Marker of Kidney Disease: Review of the Current Literature. Disease Markers, 2015, Article ID: 382918. https://doi.org/10.1155/2015/382918

[36] Akinhanmi, T.F., Ademuyiwa, O., Odukoya, O.O., Babayemi, D.O., Ogunlesi, A.O., Adamson, I. and Akinhanmi, A.O. (2016) Amelioration of Lead Toxicity in an Occupationally Exposed Population with Ascorbic Acid. Journal of Chemical Society of Nigeria, 41, 69-75.

[37] Esimai, O.A. and Awotoye, O.O. (2009) Estimation of Lead in Urine of School Children in South western Nigeria and Effect of Ascorbic Intervention. African Journal of Environmental Science and Technology, 3, 370-375.

[38] Dawson, E.B., Evans, D.R., Harris, W.A., Teter, M.C. and McGanity, W.J. (1999) The Effect of Ascorbic Acid Supplementation on the Blood Lead Levels of Smokers. Journal of the American College of Nutrition, 18, 166-170. https://doi.org/10.1080/07315724.1999.10718845

[39] Flora, G., Gupta, D. and Tiwari, A. (2012) Toxicity of Lead: A Review with Recent Updates. Interdisciplinary Toxicology, 5, 47-58. https://doi.org/10.2478/v10102-012-0009-2 
[40] Hsu, P.-C. and Guo, Y.L. (2002) Antioxidant Nutrients and Lead Toxicity. Toxicology, 180, 33-44. https://doi.org/10.1016/S0300-483X(02)00380-3

[41] Patra, R.C., Rautray, A.K. and Swarup, D. (2011) Oxidative Stress in Lead and Cadmium Toxicity and Its Amelioration. Veterinary Medicine International, 2011, Article ID: 457327. https://doi.org/10.4061/2011/457327

[42] Patra, R.C., Swarup, D. and Dwivedi, S.K. (2001) Antioxidant Effects of $\alpha$ Tocopherol, Ascorbic Acid and L-Methionine on Lead Induced Oxidative Stress to the Liver, Kidney and Brain in Rats. Toxicology, 162, 81-88.

https://doi.org/10.1016/S0300-483X(01)00345-6

[43] El-Shebly, A.A. (2009) The Role of Antioxidant (Vitamin E) in the Control of Lead $(\mathrm{Pb})$ Pollution and Enhancement of Growth within Nile Tilapia (Oreochromis niloticus). The International Journal of Applied Research in Veterinary Medicine, 7, 97-101. 